\title{
Ekonomi Islam: transaksi dan problematikanya
}

\author{
Mohamad Anton Athoillah \\ Fakultas Syariah dan Hukum UIN SGD Bandung \\ Email:kafabil@yahoo.com
}

Transaction in Islam is often criticized for not having a clear differentiator from the other transaction. Although departing from the different basic principles, but havingnot a much different impact than the other transaction. Often asked, whether Islamic economics is capitalism minus usury or socialism plus Islam? Therefore, no less important to know are, what a plus-minus of conventional transaction, what the distinguishing element between a conventional transaction with Shari'ah transaction, and whether the distinguishing element has different impact than what is produced by a conventional transaction.

Transaksi dalam Islam sering dikritik karena dianggap tidak memiliki pembeda yang jelas dari antara transaksi lainnya. Meski berangkat dari prinsip-prinsip dasar yang berbeda, tetapi memiliki dampak yang tidak begitu berbeda dari antara transaksi lainnya. Yang sering ditanyakan adalah, apakah ekonomi Islam merupakan kapitalisme minus riba atau sosialisme plus Islam? Karenanya, yang tidak kalah penting untuk diketahui adalah, apa plus-minus transaksi konvensional, apa unsur pembeda antara transaksi konvensional dengan transaksi syari'ah, dan apakah unsur pembeda itu memiliki dampak yang berbeda dari apa yang dihasilkan oleh transaksi konvensional.

Keywords: transaksion; conventional transaction, mu'amalah

\section{Pendahuluan}

Bila ditelusuri dalam Alquran, tentu tidak mudah untuk menemukan bagaimana transaksi dalam Islam dijalankan secara praktik, kecuali prinsip-prinsip umum yang harus ada ketika sebuah transaksi dijalankan, semisal adil, tidak menganiaya, tidak menipu, dan lainnya. Tidak heran bila transaksi dalam Islam terus menuai kritik yang konstruktif karena secara praktik masih dianggap memiliki unsur ketidak adilan. 
Demikian juga dengan ayat riba yang diturunkan hingga empat tahap. Ayat-ayat itu bisa dipahami dari sisi praktik yang terjadi pada saat itu semisal jual beli, karena disandingkan dengan jual beli, dipahami sebagai salah satu bentuk dari perdagangan, bahwa bila seseorang membeli sehelai kain seharga 2 dinar kemudian menjualnya 2,5 dinar, maka itu adalah transaksi yang wajar, demikian pula bila seseorang memberi pinjaman sebesar 2 dinar kemudian menerima pengembalian, maka itu juga dianggap wajar (Perwataatmaja, 2008:7). Ketika ayat riba dipahami semisal itu, mengisyaratkan bahwa dari sisi transaksi yang dilakukan, transaksi dalam Islam dikatakan berbeda karena mengalami pergeseran, dengan tidak lagi transaksi pinjam meminjam uang untuk membeli barang tetapi menjadi transaksi jual beli barang.

Atau ayat riba tidak dipahami sebagai bentuk dari perniagaan, tetapi dari sisi prinsipprinsip umum yang dijalankan, bahwa riba memiliki unsur ketidak adilan dan penganiayaan sementara jual beli tidak. Karena dinyatakan dalam Alquran bahwa riba adalah haram sementara jual beli adalah halal (QS. 2:275). Ketika ayat riba dipahami semisal itu, maka riba diharamkan karena unsur eksploitasinya daripada sebagai bunga modal itu sendiri. Setidaknya, inilah yang dipahami oleh kalangan modernis tentang alasan kenapa riba diharamkan pada saat itu (Ahmad, tt: 9).

Ulama kemudian membagi riba ke dalam dua kategori: pertama, riba yang terjadi dalam akad hutang piutang; dan kedua, riba yang terjadi akibat dari jual beli. Riba yang terjadi akibat dari jual beli terbagi ke dalam dua jenis, yaitu tambahan kuantitas atas salah satu pihak dalam transaksi barter, dan tambahan yang terjadi dalam transaksi jual beli karena penundaan pembayaran atau penyerahan barang yang dilakukan (Chamid, 2005:126-127). Baik riba kategori pertama ataupun kedua, masing-masing diperdebatkan saat ini. Riba kategori pertama dipahami sebagai bunga bank, dan riba kategori kedua dipahami sebagai kelebihan harga di atas harga tunai karena dibayar secara tidak tunai.

Muḍāabah, Murābaḥah, ba'i bi thaman ajil, dan lainnya, adalah istilah yang dikenal sebagai di antara jenis transaksi dalam Islam. Masing-masing jenis transaksi ini, bukan sebagai kategori pinjam meminjam uang untuk membeli barang, tetapi sebagai kategori jual beli barang. Hanya pada praktiknya saat ini, masing-masing jenis transaksi ini sering tidak dilakukan secara tunai, tetapi secara tidak tunai dengan harga jual yang berbeda antara harga jual secara 
tunai dengan harga jual secara tidak tunai. Selisih harga jual antara secara tunai dan secara tidak tunai ini kemudian dipertanyakan karena dianggap tidak lebih menguntungkan daripada dengan pinjam meminjam uang untuk membeli barang. Dari identifikasi masalah ini, muncul dua pertanyaan, yaitu apa plus-minus transaksi konvensional dan unsur pembeda antara transaksi konvensional dan transaksi syari'ah. Dari dua pertanyaan ini, maka akan ditemukan jawaban dari satu pertanyaan yang menjadi rumusan masalah dalam tulisan ini, yaitu apakah unsur pembeda dalam transaksi syari'ah memiliki dampak yang berbeda dari apa yang dihasilkan oleh transaksi konvensional.

\section{Transaksi dalam Islam}

Berbagai pernyataan kritis sering menerpa pada istilah ekonomi Islam, semisal: Apakah ekonomi Islam merupakan kapitalisme minus riba atau sosialisme plus Islam? Atau kritikan kepada para ekonomi Islam yang lebih berhasil menjelaskan apa yang bukan ekonomi Islam, daripada menentukan apa yang membuat ekonomi Islam berbeda sama sekali dengan sistem ekonomi lain (Iswadi, 2007: 52). Karenanya, upaya yang tidak kalah pentingnya bagi para ekonom muslim adalah menjelaskan bahwa ekonomi Islam tidak hanya sekedar istilah disertai dengan akad basmalah, tetapi juga menjelaskan bahwa ekonomi Islam memang berbeda dan menguntungkan bagi semua pihak daripada sistem ekonomi lainnya.

Kritik terhadap sistem kapitalisme dan sosialisme dikemukakan, di antaranya oleh Taqiyuddin al-Nabhani. Menurut al-Nabhani (2009: 5-6), sistem ekonomi kapitalis dibangun dengan tiga kerangka dasar: pertama, kelangkaan atau keterbatasan barang-barang dan jasajasa yang berkaitan dengan kebutuhan manusia; kedua, nilai suatu barang yang dihasilkan; dan ketiga, harga serta peranan yang dimainkan dalam produksi, konsumsi, dan distribusi.

Apa yang dipahami dari kelangkaan barang dan jasa di atas, bahwa sistem kapitalisme memandang setiap barang adalah alat pemuas kebutuhan-kebutuhan manusia yang bisa diindera atau dirasakan, dan setiap jasa adalah alat pemuas kebutuhan-kebutuhan manusia yang bisa dirasakan tetapi tidak bisa diindera. Sementara apa yang diabaikan oleh sistem kapitalisme ini adalah kebutuhan-kebutuhan yang bersifat non-fisik, semisal rasa bangga, atau kebutuhan spiritual, penyucian, yang semua itu tidak dikenal keberadaannya menurut sistem mereka (al-Nabhani, 2009:6). 
Demikian juga dengan nilai suatu barang yang dihasilkan, bahwa nilai barang itu diukur sesuai dengan tingkat kegunaannya, yang bisa jadi juga berkaitan dengan individu tertentu, bisa jadi juga berkaitan dengan barang lain. Ada dua nilai yang dikenal, yaitu nilai guna dan nilai tukar. Bagaimanapun, nilai guna suatu barang tidak bisa ditentukan berdasarkan pandangan produsen saja, karena pada saat itu kegunaan benar-benar ditentukan oleh penawaran saja, demikian juga tidak bisa ditentukan berdasarkan pandangan konsumen, karena pada saat itu kegunaan benar-benar ditentukan oleh permintaan, tetapi semestinya nilai itu dikendalikan secara seimbang antara penawaran dan permintaan, sehingga kegunaannya itu akan didapatkan pada batas unit paling akhir untuk memenuhi kebutuhan (al-Nabhani, 2009:9).

Sementara peran yang dimainkan oleh harga dalam kegiatan produksi, konsumsi, dan distribusi adalah karena struktur harga itulah yang menentukan siapa produsen-produsen yang boleh masuk ke dalam area produksi dan siapa dari antara mereka yang tetap akan menjauhi kelompok produsen itu; dengan cara yang sama, juga dipergunakan untuk menentukan siapa konsumen yang boleh menikmati pemenuhan kebutuhan-kebutuhannya dan siapa dari antara mereka yang tetap kebutuhan-kebutuhannya tidak terpenuhi. Bagi mereka, struktur harga merupakan metode paling akurat untuk mendistribusikan barangbarang dan jasa-jasa kepada masyarakat. Adapun apa yang diabaikan dari sistem kapitalis ini adalah menjauhi pembahasan aktifitas manusia untuk mencurahkan tenaganya karena dorongan moral atau spiritual (al-Nabhani, 2009:12-13).

Berbeda dengan sistem kapitalisme, demikian juga kritik terhadap sistem sosialisme. Masih menurut al-Nabhani (2009:30), sementara sistem ekonomi sosialis memiliki tiga prinsip: pertama, mewujudkan persamaan secara riil; kedua, menghapuskan pemilikian individu secara keseluruhan atau sebagian; dan ketiga, mengatur produksi dan distribusi secara kolektif.

Masih terjadi perdebatan di antara mereka tentang ketiga prinsip di atas. Menurut alNabhani (2009: 30-32), pertama, dari bentuk kesamaan secara riil yang ingin mereka realisasikan itu tidak sama. Sebagian kelompok melihatnya sebagai kesamaan dalam segala hal yang bisa dimanfaatkan. Sebagian lain melihatnya, bahwa pembagian kerja harus dilakukan menurut kemampuan tiap orang sementara pembagian hasilnya harus dilakukan menurut kebutuhan masing-masing. Sebagian lain melihatnya sebagai kesamaan dalam masalah faktorfaktor produksi, dilihat dari segi bahwa benda-benda itu kenyataannya tidak cukup untuk 
memenuhi kebutuhan-kebutuhan tiap orang. Kedua, dari standar penghapusan kepemilikan. Sebagian kelompok melihatnya bahwa pemilikan individu harus dihapuskan sama sekali. Sebagian lain melihatnya bahwa pemilikan individu yang berhubungan dengan barang-barang produktif, yang harus dihapuskan, yang disebut dengan sosialis kapitalis. Sebagian lain tidak mengatakan tentang penghapusan pemilikan khusus, kecuali yang berhubungan dengan tanah pertanina, yang disebut dengan sosialis pertanian. Sebagian lain melihat bahwa kondisi yang di dalamnya terdapat kemaslahatan umum yang menganjurkan perubahan status milik khusus menjadi milik umum, yang disebut dengan sosialis negara. Ketiga, dari pengaturan produksi dan distribusi secara kolektif.Sebagian dari mereka menghendaki pengaturan itu diserahkan kepada negara. Sebagian lain menghendaki pengaturan itu diserahkan kepada sekelompok pekerja yang terorganisir, di bawah komando pimpinan-pimpinan mereka.

Masing-masing ketiga prinsip di atas bisa diperdebatkan.Menurut al-Nabhani (2009:3942), bentuk kesamaan secara riil tentu mustahil, karena kesamaan, dari segi kesamaan itu sendiri sebenarnya tidak bisa terjadi secara riil, maka kesamaan itu adalah sesuatu yang tidak pernah terjadi. Demikian juga dengan pemilikan khusus secara total, bahwa itu bertentangan dengan fitrah manusia. Sementara mengatur produksi dan distribusi secara kolektif itu sebenarnya tidak bisa dilakukan dengan cara menciptakan gejolak dan goncangan di tengahtengah manusia, serta menciptakan dendam dan permusuhan di antara mereka, antara sebagian orang dengan sebagian lain.

Ekonomi adalah istilah untuk suatu sebutan, yaitu kegiatan mengatur urusan harta kekayaan, baik yang menyangkut kegiatan memperbanyak jumlah kekayaan dan pengadaanya, ataupun yang berhubungan dengan mekanisme pendistribusiannya (al-Nabhani, 2009:47). Sehingga ekonomi Islam, sebagaimana juga dikatakan Chapra (2001:33), dapat didefinisikan sebagai cabang pengetahuan yang membantu mewujudkan kesejahteraan manusia melalui alokasi dan distribusi sumber daya yang langka yang sesuai dengan ajaran Islam tanpa terlalu membatasi kebebasan individu atau menciptakan makro ekonomi yang berkelanjutan dan ketidakseimbangan ekologi.

Ekonomi Islam memiliki misi demi terwujudnya persamaan martabat di antara umat manusia sehingga di sini perlu ditegakkan keadilan terutama dalam distribusi pendapatan. Sementara secara makro, misi ini mengarah kepada terwujudnya negeri yang baik, yang adil 
ljtihad, Jurnal Wacana Hukum Islam dan Kemanusiaan, Volume 13, No. 2, Desember 2013: 269-289

dan makmur, serta diridlai Allah Swt (Perwataatmaja, 2008:10). Karenanya, ekonomi Islam memiliki dasar yang berbeda dari sistem ekonomi lain, yang menurut Abu Saud (1996:1617), ada tiga konsep dasar ekonomi Islam: pertama, ilmu ekonomi dititik-beratkan pada usaha mencapai tujuan; kedua, beriman kepada ke-Esaan Allah; dan ketiga, dalam situasi apapun aturan Islam harus berlaku.

Konsep dasar ini dianggap berbeda dengan apa yang dimiliki sistem ekonomi lainnya. Sebagaimana dalam artikel yang ditulis Joni Tamkin bin Borhan (2008:94-95), bahwa dalam teori ekonomi komunis, bahwa pembangunan ekonomi hanya dilihat sebagai bagian daripada konsep kebendaan, atau dalam sistem ekonomi kapitalis yang hanya melihat dari aspek pembangunan kebendaan dan fisik yang terus mengabaikan pembangunan nilai-nilai moral dan spiritual serta pembangunan diri manusia itu sendiri. Menurutnya (2008:95), konsep pembangunan ekonomi dalam Islam adalah bersifat komprehensif dan bersepadu yang meliputi pembangunan dalam akhlak, kerohanian, dan kebendaan.

Ekonomi Islam dianggap sebagai solusi karena beberapa alasan: pertama, teori ekonomi Barat (kapitalisme) telah menimbulkan ketidak adilan ekonomi yang sangat dalam, khususnya karena sistem moneter yang hanya menguntungkan Barat melalui hegemoni mata uang kertas dan sistem ribawi; kedua, kapitalisme tidak mampu mengentaskan masalah kemiskinan dan ketimpangan pendapatan; ketiga, paradigma tidak mengacu kepada kepentingan masyarakat secara menyeluruh; keempat, teori ekonominya tidak mampu menyelaraskan hubungan antara negara-negara di dunia; dan kelima, terlalaikannya pelestarian sumber daya alam (Aditya, 2008:88).

Sementara ekonomi kapitalisme dianggap sebagai biang dari terpuruknya ekonomi dunia.Setidaknya, di antara akibat buruk dari kapitalisme adalah berkuasanya kaum mayoritas atas kaum minoritas yang kepentingan-kepentingannya dikuasai oleh kaum mayoritas.Aspek ekonomi kapitalis lebih menindas karena tidak menentukan kendali atas eksploitasi ekonomi. Karena ia kerap memperoleh investasi yang tidak terbatas dalam setiap proyek yang sah ataupun tidak (al-Shadr, 2002:67-68).

Paham kapitalis yang materialis mengharuskannya melakukan ekspansi ke berbagai wilayah guna mendapatkan sumber produksi.Kegila-gilaannya terhadap harta juga mengharuskannya melakukan ekspansi ke berbagai wilayah guna memperluas pasar. Karenanya, untuk 
memperluas eksistensinya, terkadang dilakukan melalui perang dan pertumpahan darah (alShadr, 2002:70-72)

Menurut Rosadi (dalam Aditya, 2008:89), perbedaan yang mendasar antara sistem ekonomi Islam dengan sistem ekonomi lainnya khususnya sistem ekonomi kapitalis, mencakup perbedaan pandangan tentang empat hal: pertama, penetapan problematika ekonomi serta solusi untuk mengatasinya; kedua, konsep kepemilikan harta kekayaan; ketiga, konsep tentang pengelolaan kepemilikan harta; dan keempat, konsep tentang distribusi kekayaan di tengah masyarakat.

Dalam melihat problematika ekonomi dan solusinya, terdapat perbedaan antara sistem ekonomi kapitalis dengan sistem ekonomi Islam. Dalam sistem ekonomi kapitalis, persoalan ekonomi yang sesungguhnya adalah kelangkaan barang dan jasa. Ini karena manusia memiliki kebutuhan yang beraneka ragam dan jumlahnya tidak terbatas sementara sarana pemuas (barang dan jasa) yang digunakan untuk memenuhi kebutuhan manusia sangat terbatas. Dari problematika ini muncullah solusi untuk memecahkannya berupa upaya untuk meningkatkan barang dan jasa agar dapat memenuhi kebutuhan tersebut. Sementara sistem ekonomi Islam melihat, bahwa persoalan ekonomi yang sesungguhnya bukanlah kelangkaan barang dan jasa, melainkan rusaknya distribusi kekayaan di tengah masyarakat. Dari problematika ini muncullah solusi untuk memecahkannya berupa perhatian yang besar terhadap upaya perbaikan distribusi, tetapi tetapi dengan tidak mengabaikan aspek produksi dan pertumbuhan (Aditya, 2008:89-91).

Dalam melihat konsep kepemilikan harta, terdapat perbedaan antara sistem ekonomi kapitalis, sistem ekonomi sosialis, dan sistem ekonomi Islam. Dalam sistem ekonomi kapitalis, kepemilikan harta individu berikut cara untuk memperolehnya tidak dibatasi. Berbeda dalam sistem ekonomi sosialis, kepemilikan harta individu dibatasi, tetapi cara untuk memperolehnya tidak dibatasi. Demikia juga untuk menggunakan dan mengembangkan harta itu. Dalam sistem ekonomi kapitalis dan sosialis, harta yang telah dimiliki dapat dipergunakan ataupun dikembangkan secara bebas tanpa memperhatikan aspek halal dan haram serta bahayanya bagi masyarakat. Sementara dalam sistem ekonomi Islam, kepemilikan harta individu tidak dibatasi, tetapi cara untuk memperolehnya dibatasi dengan cara-cara tertentu, apakah itu dihalalkan atau diharamkan, kemudian dalam penggunaan dan pengembangannya, harta itu 
ljtihad, Jurnal Wacana Hukum Islam dan Kemanusiaan, Volume 13, No. 2, Desember 2013: 269-289

terikat dengan ketentuan halal dan haram (Aditya, 2008:91-92).

Pada akhirnya, akan terjadi pengaruh antara pelaksanaan sistem ekonomi Islam dengan non-Islam: pertama, bagi para sarjana non-muslim, materialisme merupakan nilai kehidupan yang super, sementara bagi sarjana muslim, ketinggian nilai terletak pada hubungannya dengan Allah; kedua, orang yang hidup di bawah aturan materialis adalah bagian dari masyarakat di mana materilah yang lebih berkuasa, sementara menurut Islam, individu adalah anggota masyarakat; dan ketiga, menurut paham materialisme, masyarakat diperbudak oleh materi, sementara menurut Islam, materi adalah unsur pelayanan individu atau masyarakat dan digunakan untuk memenuhi kepentingan manusia (Saud, 1996:19-20).

Demikian juga dalam melihat konsep distribusi harta kekayaan, terdapat perbedaan antara sistem kapitalis dan sosialis dengan sistem ekonomi Islam. Dalam sistem kapitalis, konsep distribusi harta lebih mengandalkan pada mekanisme pasar. Berbeda dengan kapitalis, sistem ekonomi sosialis justeru dilakukan oleh negara secara mutlak.Sementara dalam sistem ekonomi Islam, konsep distribusi selain mengandalkan mekanisme ekonomi yang wajar, juga mengandalkan mekanisme non-ekonomi, di mana ketika dianggap tidak mampu dengan menggunakan mekanisme ekonomi, maka ditempuh mekanisme non-ekonomi (Aditya, 2008:92-93).

Dari uraian di atas dapat dipahami, bahwa transaksi dalam Islam berbeda dengan transaksi lainnya. Di mana transaksi dalam Islam di dasari oleh: pertama, untuk memenuhi kebutuhan manusia yang tidak hanya bersifat fisik semata, tetapi juga non-fisik semisal rasa bangga, dan lainnya; bukan hanya untuk memenuhi kebutuhan jasmani tetapi juga kebutuhan rohani; kedua, nilai dikendalikan secara seimbang antara penawaran dan permintaan, sehingga kegunaannya itu akan didapatkan pada batas unit paling akhir untuk memenuhi kebutuhan; ketiga, aktifitas manusia tidak tergantung pada peran yang dimainkan oleh harga, tetapi juga untuk mencurahkan segenap tenaganya karena dorongan moral atau spiritual; keempat, terpenuhinya kebutuhan manusia secara jasmani dan rohani bukanlah tujuan utama, tetapi usaha untuk mencapai tujuan utama yaitu beribadah kepada Allah Swt.

Dari perbedaan dasar-dasar di atas, maka transaksi dalam Islam idealnya memiliki dampak yang berbeda. Setidaknya, dari antara dampak-dampak yang ditimbulkan adalah: pertama, terpenuhinya kebutuhan jasmani dan rohani; kedua, tidak timpangnya antara kelompok 
mayoritas dengan kelompok minoritas; ketiga, tidak bersifat menindas, karena tidak bisa dilakukan oleh kelompok minoritas; dan keempat, terpenuhinya kebutuhan kelompok minoritas.

\section{Plus-minus transaksi konvensional}

Sebelum mendiskusikan tentang bagian mana dari transaksi dalam sistem konvensional dan syari'ah yang berbeda, sehingga masyarakat muslim dianjurkan memilih transaksi dalam sistem syari'ah, terlebih dahulu perlu dijelaskan apa yang selama ini dijalankan dalam sistem konvensional. Dengan demikian akan terlihat apa yang berbeda dan berubah dari transaksi dalam sistem konvensional menuju sistem syari'ah.

Sebagaimana dikatakan di atas, perbedaan antara transaksi konvensional dengan transaksi syari'ah ditentukan di antaranya karena pergeseran jenis transaksi dari pinjam meminjam uang untuk membeli barang menjadi transaksi jual beli barang. Ketika seseorang hendak memiliki barang, bila melalui konvensional ia akan melakukan transaksi sebagai peminjam uang, dan bila melalui syari'ah ia akan melakukan transaksi sebagai pembeli barang. Masingmasing dari dua transaksi ini masih diperdebatkan, karena dalam transaksi konvensional masih dimungkinkan memiliki unsur keadilan, dan dalam transaksi syari’ah masih dimungkinkan memiliki unsur ketidak adilan.

Dari transaksi konvensional, lahirlah apa yang dinamakan dengan bunga. Bunga dipahami sebagai persentase kelebihan sejumlah uang pada perjanjian penyerahan di masa depan. Bunga ini merupakan tambahan yang diperoleh berdasarkan persentase pada modal tanpa mempertimbangkan keadaan proyek di masa datang untung atau rugi. Sementara dalam dunia nyata, optimalisasi atas uang atau modal tergantung dari jenis usaha, lama usaha, keadaan pasar, beserta jaringannya, serta stabilitas politik, yang mana akan memunculkan pula resiko kerugian, sehingga padanya diperlukan sharing (Pujiyono, 2004:46).

Bunga sering dianggap sebagai sosok yang paling bersalah, terhadap berbagai persoalan ekonomi. Sebagaimana dalam artikel yang ditulis Arif Pujiyono (2004: 48-49), bahwa suku bunga bisa menimbulkan berbagai persoalan. Sebut saja di antarannya adalah menimbulkan dampak inflatoir. Ketidak adilannya dapat ditunjukkan pada sistemnya yang bersifat cost concept. Semakin tinggi suku bunga, semakin tinggi pula harga yang akan ditetapkan atas 
ljtihad, Jurnal Wacana Hukum Islam dan Kemanusiaan, Volume 13, No. 2, Desember 2013: 269-289

suatu barang. Bukan hanya itu, bahwa utang, dengan rendahnya tingkat penerimaan peminjam dan tingginya biaya bunga, akan menjadikan peminjam tidak pernah keluar dari ketergantungan, terlebih lagi ketika bunga atas uang tersebut dibungakan lagi. Demikian juga sistem bunga berdampak terhadap perubahan kurs mata uang asing, bahwa ketika suku bunga turun, masyarakat cenderung untuk memegang uang asing, dan ini mengakibatkan harganya naik, sehingga nilai uang dalam negeri menjadi terdepresiasi.

Larangan bunga masih menjadi sebuah isu yang kompleks. Dalam artikel yang ditulis oleh John R. Presley dan John G. Sessions (1994:586), setidaknya beberapa alasan dapat dirangkum: pertama, seorang individu yang berupaya untuk tidak konsumtif, dengan menabung, tidak berhak secara otomatis mendapatkan imbalan tambahan simpanan karena upaya itu; kedua, tidak akan ada alasan yang dapat dibenarkan mengapa sipemberi pinjaman harus otomatis menerima hadiah hanya melalui pinjaman yang berikannya itu; ketiga, perbedaan yang mencolok antara uang dan modal, bahwa uang tidak disamakan dengan modal, meskipun mungkin dianggap sebagai modal potensial; keempat, keadilan memiliki dua dimensi, yaitu pemasok modal memiliki hak untuk berbagi keuntungan yang sepadan dengan risiko dan usaha kerja, dan ini tidak serta merta ditentukan berdasarkan suku bunga pasar yang sedang berjalan, tetapi dengan nilai pengembalian pada proyek individu; dan kelima, hubungan kreditur/debitur menjadi rusak.

Sebagaimana dikatakan di atas, bahwa ayat-ayat riba tidak selamanya dipahami sebagai bentuk dari perniagaan nilai uang. Tetapi ayat-ayat riba dipahami dari prinsip-prinsip umum yang dijalankan, bahwa di dalam riba terdapat unsur ketidak adilan dan penganiayaan (Athoillah dan Al-Hakim 2013), sementara di dalam jual beli tidak terdapat unsur-unsur semisal itu. Ketika riba dipahami sebagai istilah yang di dalamnya terdapat unsur ketidak adilan dan penganiayaan, sementara dalam praktik lembaga konvensional, dominasi sistem bunga dalam berbagai aktifitas perekonomiannya berkonsekuensi terhadap operasionalisasi perbankan dengan bunga sebagai instrumen utamanya (Pujiyono, 2004:46), maka pemahaman tentang riba atau bunga bank menjadi penting. Pemahaman ini bisa ditelusuri, di antaranya dengan mengetahui cara perhitungan bunga dan penetapan bunga.

Ketika seseorang menabung di lembaga konvensional, maka ia akan mendapatkan tambahan simpanan berupa bunga sesuai dengan yang ditetapkan, sementara di lembaga 
syari'ah, maka ia akan mendapatkan tambahan simpanan berupa bagi hasil sesuai dengan yang ditetapkan oleh lembaga itu. Dari dua mekanisme ini, mekanisme bunga dianggap tidak baik karena telah memunculkan jarak dan distorsi sehingga menimbulkan ketidakterkaitan langsung antara sektor finansial dengan sektor riil, yang pada akhirnya menimbulkan pertumbuhan ekonomi yang semu atau buble economy (Pujiyono, 2004:46), sementara syari'ah dianggap memiliki keterkaitan langsung antara sektor finansial dengan sektor riil. Mekanisme ini tidak berlaku ketika seorang debitur mendapatkan kredit, baik di lembaga konvensioal ataupun syari'ah, karena bunga ataupun keuntungan yang didapat oleh kedua lembaga itu justeru diberikan oleh debitur. Yang harus diuji di sini adalah, apakah lembaga konvensional ataupun syari'ah sama-sama memperhatikan keterkaitan langsung antara sektor finansial dengan sektor riil, atau sama-sama tidak memperhatikan.

Dalam transaksi konvensional, bunga dihitung melalui tiga cara: pertama, flate rate; kedua, sliding rate; dan ketiga, anuitas. Flat rate adalah perhitungan bunga didasarkan pada plafond kredit dan besarnya bunga yang dibebankan dialokasikan secara proporsional sesuai dengan jangka waktu kredit. Dengan cara ini, jumlah pembayaran pokok dan bunga kredit setiap bulan sama besarnya. Rumus yang digunakan untuk flate rate adalah:

Suku bunga per bulan $=(p \times i \times t): j b P=$ pokok pinjaman; $i=$ suku bunga/tahun; $t=$ jumlah tahun kredit; dan jb = jumlah bulan kredit

Dari rumus di atas, ketika debitur mendapatkan kredit sebesar Rp. 60.000.000,- selama satu tahun dengan tingkat bunga 11\% per tahun flat rate, maka bunga per bulan dengan total bunga yang didapat adalah:

Suku bunga per bulan adalah $=$ Rp.550.000,-

Total bunga adalah $\quad=$ Rp.6.600.000.-

Dengan tabel,

\begin{tabular}{ccccc}
\hline Bulan & Saldo & Angs. Pokok & Angs. Bunga & Jml. Angsuran \\
\hline 1 & Rp. 60.000.000,- & Rp. 5.000.000,- & Rp. 550.000,- & Rp. 5.550.000,-- \\
2 & Rp. 55.000.000,- & Rp. 5.000.000,- & Rp. 550.000,- & Rp. 5.550.000,- \\
11 & Rp. 10.000.000,- & Rp. 5.000.000,- & Rp. 550.000,- & Rp. 5.550.000,- \\
12 & Rp. 5.000.000,- & Rp. 5.000.000,- & Rp. 550.000,- & Rp. 5.550.000,- \\
& Jumlah & Rp.60.000.000,- & Rp.6.600.000,- & Rp.66.600.000,- \\
\hline
\end{tabular}


Dari tabel di atas, terlihat setiap bulan debitur harus membayar kredit secara tetap, dengan keuntungan yang mungkin di dapat, bahwa ketika debitur hendak membayar kredit sebelum jatuh tempo 1 tahun, ia akan membayar sisa pinjaman secara seimbang.

Sliding rate adalah perhitungan bunga dilakukan setiap akhir periode pembayaran angsuran, dan dihitung dari saldo akhir setiap bulannya. Dengan cara ini, jumlah angsuran yang dibayar debitur setiap bulannya akan semakin mengecil, karena angsuran bunga yang semakin kecil. Rumus yang digunakan untuk sliding rate adalah:

Suku bunga per bulan $=(\operatorname{sp} \times$ i $\times(30 / 360)$ $\mathrm{sP}=$ saldo pokok pinjaman; $\mathrm{i}=$ suku bunga/tahun; $30=$ jumlah hari dalam satu bulan; dan $360=$ jumlah hari dalam satu tahun

Dari rumus di atas, ketika debitur mendapatkan kredit sebesar Rp. 60.000.000,- selama satu tahun dengan tingkat bunga 11\% per tahun sliding rate, maka total bunga yang di dapat adalah:

Total bunga adalah = Rp.3.575.000,-

Dengan tabel,

\begin{tabular}{ccccc}
\hline Bulan & \multicolumn{1}{c}{ Saldo } & Angs. Pokok & Angs. Bunga & Jml. Angsuran \\
\hline 1 & Rp. 60.000.000,- & Rp. 5.000.000,- & Rp. 550.000,- & Rp. 5.550.000,-- \\
2 & Rp. 55.000.000,- & Rp. 5.000.000,- & Rp. 504.167,- & Rp. 5.504.167,-- \\
11 & Rp. 10.000.000,- & Rp. 5.000.000,- & Rp. 91.667,- & Rp. 5.091.667,-- \\
12 & Rp. 5.000.000,- & Rp. 5.000.000,- & Rp. 45.833,- & Rp. 5.045.833,-- \\
\hline & Jumlah & Rp.60.000.000,- & Rp.3.575.000,- & Rp.63.575.000,- \\
\hline
\end{tabular}

Dari tabel di atas, terlihat setiap bulan debitur harus membayar kredit secara menurun sesuai dengan saldo dan bunga yang didapat dari saldo akhir, dengan keuntungan yang mungkin di dapat, bahwa ketika debitur hendak membayar kredit sebelum jatuh tempo 1 tahun, ia akan membayar sisa pinjaman secara seimbang.

Anuitas adalah angsuran bulanan yang dibayar debitur tidak berubah selama jangka waktu kredit, tetapi komposisi besarnya angsuran pokok ataupun angsuran bunga akan berubah di mana angsuran pokok akan semakin besar dan angsuran bunga akan semakin kecil. Rumus yang digunakan untuk anuitas adalah: 
Suku bunga per bulan $=(\operatorname{sp} \times \mathrm{i} \times(30 / 360) \mathrm{sP}=$ saldo pokok pinjaman; $\mathrm{i}=$ suku bunga $/$ tahun; 30 = jumlah hari dalam satu bulan; dan $360=$ jumlah hari dalam satu tahun

Dari rumus di atas, ketika debitur mendapatkan kredit sebesar Rp. 60.000.000,- selama satu tahun dengan tingkat bunga $11 \%$ per tahun anuitas, maka total bunga yang di dapat adalah:

Total bunga adalah $=$ Rp.3.634.794,-

Dengan tabel,

\begin{tabular}{ccccc}
\hline Bulan & Saldo & Angs. Pokok & Angs. Bunga & Jml. Angsuran \\
\hline 1 & Rp. 60.000.000,- & Rp. 4.752.900,- & Rp. 550.000,- & Rp. 5.302.900,- \\
2 & Rp. 55.247.100,- & Rp. 4.796.468,- & Rp. 506.432,- & Rp. 5.302.900,- \\
11 & Rp. 10.461.726,-- & Rp. 5.207.001,-- & Rp. 95.899,- & Rp. 5.302.900,- \\
12 & Rp. 5.254.726,- & Rp. 5.254.732,-- & Rp. 48.168,- & Rp. 5.302.900,- \\
\hline \multicolumn{2}{r}{ Jumlah } & Rp.60.000.000,- & Rp.3.634.794,- & Rp.63.634.794,-- \\
\hline
\end{tabular}

Dari tabel di atas, terlihat setiap bulan debitur harus membayar kredit secara menurun sesuai dengan saldo dan bunga yang didapat dari saldo akhir, dengan keuntungan yang mungkin di dapat, bahwa ketika debitur hendak membayar kredit sebelum jatuh tempo 1 tahun, ia akan membayar sisa pinjaman secara seimbang.

Dari ketiga cara di atas, cara sliding rate bisa dianggap sebagai cara yang menguntungkan pihak kreditor sekaligus menguntungkan pihak debitur. Karena ketika debitur hendak membayar lunas kreditnya sebelum jatuh tempo, ia akan membayar jumlah modal sisa secara adil sesuai dengan jumlah tempo yang sudah dilaluinya.

Adapun anuitas bisa dianggap sebagai cara yang paling disukai pihak kreditor, karena menguntungkan pihak kreditor tetapi merugikan pihak debitur. Karena ketika debitur hendak membayar lunas kreditnya sebelum jatuh tempo, maka ia harus membayar jumlah pinjaman sisa yang tidak jauh berbeda dengan jumlah pinjaman awal.

Dalam transaksi konvensional, bunga ditetapkan melalui dua cara: pertama, suku bunga tetap; dan kedua, suku bunga mengambang. Untuk suku bunga tetap, semisal contoh di atas, maka bunga akan tetap sebesar 11\% selama jangka waktu yang diperjanjikan. Sedangkan 
ljtihad, Jurnal Wacana Hukum Islam dan Kemanusiaan, Volume 13, No. 2, Desember 2013: 269-289

suku bunga mengambang, maka bunga akan berubah-ubah, terkadang naik dan terkadang turun.

\section{Problematika transaksi syari'ah}

Produk pembiayaan pada Lembaga Keuangan Syari'ah, atau dalam hal ini adalah perbankan Islam dapat dibagi ke dalam dua model: pertama, model bagi hasil semisal musharakah dan muḍarabah; dan kedua, model pendapatan tetap semisal murabahah dan ba’i bi thaman ajil (BBA). Dari dua model ini, model kedua lebih mendominasi (Arsyianti, tt: 32). Yang pertama diistilahkan juga sebagai pembiayaan berbasis ekuitas, dan yang kedua sering diistilahkan juga sebagai pembiayaan berbasis utang (Ismal, tt:101). Berikut ini adalah di antara contoh jasa atau produk yang ditawarkan, yang memang mendominasi, yaitu, Murābaḥah dan ba’i bi thaman ajil.

\section{Murābaḥah}

Istilah Murābahah sudah dikenal dari masa klasik. Sebagaimana dalam artikel yang ditulis Muhamad Nadratuzzaman Hosen (2012:166-167), istilah ini sudah dikenalkan dan didefinisikan oleh para fuqaha, dari Ibn Rusyd al-Maliki, Ibrahim al-Halabi al-Hanafi, alMawardi al-Syafi'i, dan Ibn Quddamah al-Hanbali. Dari sekian definisi yang diberikan oleh mereka, dapat disimpulkan yaitu menjual barang dengan harga beli ditambah keuntungan yang diketahui.

Pada praktiknya, ternyata Muräbahah tidak mudah untuk diterapkan. Karena tidak mudah, kemudian muncullah istilah Murābahạh li al-āmr bi ashirāa (MLAB). Sebagaimana dalam artikel yang Muhamad Nadratuzzaman Hosen (2012:168-169), istilah ini sudah dikenalkan juga oleh ulama kontemporer semisal Sami Hammud, Rafiq Yunus Mashri, Wahbah Zuhaili, dan Ahmad Salim Mulhim. Dari sekian definisi yang diberikan oleh mereka, Ahmad Salim Mulhim misalnya, menyatakan bahwa MLAB adalah permintaan pembelian pada barang kepada bank dengan kriteria dari nasabah dan janji oleh kedua belah pihak, pihak pertama janji membeli dan pihak kedua janji menjual dengan harga dan keuntungan yang disepakati di awal.

Apabila ditelusuri, skema dari murābaḥah di atas sama dengan skema murābaḥah yang difatwakan DSN NO:04/DSN-MUI/IV/2000 tentang Murabahah. Dalil penetapan 
murabahah dalam fatwa DSN di atas bisa dikategorikan ke dalam empat, yaitu Al-Qur'an, Hadis, Ijmak, dan Kaidah fikih. Dalil dari al-Qur'an dikutip dari surat al-Nisā', 4:29; alBaqarah, 2:275; al-Māidah, 5:1; al-Baqarah, 2:280. Dalil dari hadis dikutip dari riwayat alBaihaqi dan Ibn Mājah yang menyatakan bahwa jual beli harus dilakukan suka sama suka; riwayat Ibn Majah tentang tiga hal yang mengandung berkah, satu di antaranya adalah jual beli tidak secara tunai; riwayat Tirmidhi tentang perdamaian yang diperbolehkan kecuali perdamaian yang mengharamkan yang halal atau menghalalkan yang haram; riwayat jama'ah tentang penundaan bayaran bagi yang mampu adalah kezaliman; riwayat al-Nasa’i tentang penundaan pembayaran bagi yang mampu menghalalkan harga diri dan pemberian sanksi kepadanya; riwayat dari Zaid ibn Aslam tentang bolehnya uang muka dalam jual beli. Dalil dari Ijmak ulama tentang bolehnya jual beli murabahah kemudian kaidah fiqh yang menyatakan bahwa semua bentuk muamalah boleh untuk dilakukan kecuali ada dalil yang mengharamkannya.

Dari sumber-sumber di atas dapat dipahami, bahwa umumnya dalil yang digunakan bersifat umum, yaitu bolehnya melakukan transaksi jual beli. Yang tidak didapatkan dari fatwa dengan dalil yang digunakannya adalah ketentuan bagaimana keuntungan itu didapat, sehingga riba yang dipahami masih pada kategori riba yang pertama, yaitu riba yang terjadi dalam akad hutang piutang, dan bukan kategori riba yang kedua, yaitu riba yang terjadi akibat dari jual beli.

Karena perbedaan praktik inilah, fuqaha sependapat tentang bolehnya murābaḥah, tetapi tidak sependapat tentang bolehnya MLAB. Dalam artikel yang ditulis Muhamad Nadratuzzaman Hosen (2012:172-175), perbedaan tersebut terbagi ke dalam dua pendapat: pertama, membolehkan MLAB dengan keharusan melaksanakan janji oleh pihak yang melakukan akad; dan kedua, melarang akad MLAB apabila terdapat keharusan memenuhi perjanjian bagi pihak yang melakukan akad. Mereka yang membolehkan beralasan: Kaidah fiqh yang menyatakan bahwa pada dasarnya hukum asal dari muamalat adalah boleh dilakukan, kecuali ada dalil yang mengharamkannya; Keumuman dalil Al-Qur'an dan sunnah yang menunjukkan pada bolehnya jual beli; Pendapat fuqaha klasik yang membolehkan akad yang serupa dengan MLAB; Muamalat dasarnya adalah kemaslahatan; Kemudahan bagi manusia. Adapun mereka yang melarang beralasan: MLAB dilarang karena termasuk 
ljtihad, Jurnal Wacana Hukum Islam dan Kemanusiaan, Volume 13, No. 2, Desember 2013: 269-289

pada jual beli barang yang tidak dimiliki atau jual beli barang yang belum diketahui; MLAB adalah akad batil, yaitu tidak sahnya akad yang diakibatkan oleh objek barang, karena termasuk jual beli muallaq; MALB masuk ke dalam kategori hilah atau mencari alasan, pada pinjaman dengan riba; MLAB termasuk jual beli 'inah; MAB termasuk jual beli hutang dengan hutang yang dilarang oleh Nabi saw; MLAB termasuk dalam akad dua jual beli dalam satu akad; dan (7) Fuqaha klasik tidak membolehkannya.

Dalam istilah Syafi'i Antonio (2007:103) transaksi murābahah semisal di atas dikenal juga dengan Murābaḥah Kepada Pemesan Pembelian (Murābaḥah KPP). Dinamakan demikian, karena sipenjual semata-mata mengadakan barang untuk memenuhi kebutuhan si pembeli yang memesannya.

Ada berbagai alasan kenapa debitur memilih transaksi MKPP. Menurut Syafi'i Antonio (2007:103), di antara alasannya berakar pada dua hal: pertama, mencari pengalaman; dan kedua, mencari pembiayaan.

Murabahah memiliki sisi keuntungan dan resiko. Menurut Syafi'i Antonio (2007:106), MKPP ini memiliki sisi keuntungan dan resiko. Keuntungannya adalah adanya keuntungan yang muncul dari selisih harga beli penjual dengan harga jual dari nasabah. Sementara menurut Roosly (dalam Ismal, t.th:102), murabahah menjadi favorit untuk digunakan karena: pertama, tingkat pengembalian murabahah ditentukan, tetap,dan terus; kedua, pembiayaan perdagangan tidak memerlukan banyak upaya untuk memantau, bekerja sama atau mengevaluasi seperti pembiayaan berbasis investasi; dan ketiga, resiko kelalaian adalah relatif rendah. Sementarabagi pengusaha, murabahahadalah lebih baikkarena: pertama, laju tetap sepanjang periode pengembalian pembayaran; kedua, tidak adabiaya untuk keterlambatan pembayaran/kelalaian; dan ketiga, memperlakukan aset yang dibeli sebagai jaminan.

Sedangkan dari antara resikonya adalah: pertama, mungkin terjadinya kelalaian, yaitu nasabah sengaja tidak membayar angsuran; kedua, fluktuasi harga komparatif. Ini terjadi bila harga suatu barang di pasar naik setelah bank membelikannya untuk nasabah, sementara bank tidak bisa mengubah harga jual beli tersebut; ketiga, penolakan nasabah, karena bisa saja barang yang dikirim kemudian ditolak dengan berbagai alasan; dan keempat, di jual, karena MKPP bersifat jual beli dengan utang, maka kontrak setelah ditandatangani, barang itu menjadi milik nasabah sehingga ia bebas melakukan apa saja termasuk menjualnya, sehingga 
ini mengandung resiko terjadinya kelalaian akan besar (Antonio, 2007:106-107). Demikian juga dalam artikel yang ditulis Rifki Ismal (tt:102), murabahah memiliki beberapa resiko, yaitu: resiko harga; kedua, resiko kelalaian; ketiga, resiko komoditi; dan keempat, resiko pasar.

\section{Ba'i bi thaman ajil (BBA)}

BBA merupakan pembiayaan jual beli yang pembayarannya dilakukan secara berangsur dalam jangka panjang. Dipahami juga sebagai transaksi jual beli dengan pembayaran tertunda pada harga tertentu, termasuk marjin keuntungan yang disepakati oleh kedua pihak, nasabah dan bank syari'ah, yang terlibat (Arsyianti, tt:33).

Penelitian dilakukan oleh Laily Dwi Arsyianti dan Irfan Syauqi Beik untuk melihat lebih jauh faktor-faktor yang mempengaruhi, mengapa harga pembiayaan pada bank syari'ah lebih tinggi dibandingkan pada bank konvensional. Adapun yang menjadi objeknya adalah tiga bank yang ada di Malaysia, yaitu Maybank Islamic Berhad, Bank Islam Malaysia Berhad, dan Public Islamic Bank Berhad.

Dalam penelitian yang dilakukan oleh Arsyianti (tt:33), marjin keuntungan diperbandingkan melalui formulasi sebagai berikut,

$$
\begin{aligned}
\text { BBA Marjin Keuntungan }= & \text { Cost of Islamic Deposits }+ \text { Biaya Overheads }+ \text { Premi } \\
& \text { Resiko Inflasi }+ \text { Premi Resiko Kegagalan Nasabah } \\
& \text { Pembiayaan }
\end{aligned}
$$

Dengan,

$$
\begin{aligned}
\text { Bunga Kredit }= & \text { Cost of Deposits }+ \text { Biaya Overheads }+ \text { Premi Resiko } \\
& \text { Inflasi }+ \text { Premi Resiko Kegagalan Nasabah Pembiayaan }
\end{aligned}
$$

Dari formulasi di atas, Arsyianti (tt:34-38) memperbandingkan tiga variabel, yaitu cost of deposits, biaya overhead, dan premi resiko kegagalan. Dari ketiga variabel di atas, disimpulkan: pertama, cost of deposits (biaya yang dikeluarkan oleh bank untuk dibagi kepada nasabah penabung) pada tiga bank syari'ah di Malaysia lebih kecil dibandingkan dengan apa yang diberikan bank konvensional; kedua, biaya overheads (biaya yang dikeluarkan oleh bank untuk membayar operasional tidak langsung) pada tiga bank syari'ah di Malaysia 
terus menunjukkan perbaikan; dan ketiga, premi resiko kegagalan pada tiga bank syari'ah di Malaysia menghadapi premi resiko kegagalan yang lebih tinggi dibandingkan bank konvensional. Ini dipahami bahwa bank syari'ah terlihat menghadapi nasabah yang tidak sebaik nasabah pada bank konvensional.

Berbeda dengan transaksi dalam sistem ekonomi konvensional, dalam transaksi syari’ah tidak dikenal adanya istilah bunga, tetapi bagi hasil bagi modal simpanan dan keuntungan yang ditetapkan bagi transaksi jual beli barang atau pinjaman, karena nasabah tidak akan ke bank kecuali untuk meminjam dana. Khusus kategori transaksi jual beli barang atau pinjaman, transaksi syari'ah yang dilakukan Lembaga Keuangan Syari'ah atau dalam hal ini adalah perbankan syari'ah, lebih memilih untuk mengikuti suku bunga yang ditentukan oleh BI untuk mendapatkan keuntungan yang ditetapkan, kemudian dihitung dan diberlakukan secara anuitas, sehingga ini lebih menguntungkan kreditor dan agak merugikan debitur. Tidak terkecuali untuk model transaksi yang diberlakukan beberapa tahun ini, yaitu model step-up marjin. Di mana dengan model yang kedua ini, debitur yang melakukan kontrak di atas lima tahun, dituntut untuk tidak melakukan pembayaran tunai sebelum lima tahun, karena bila tidak, debitur harus membayar lebih dari pinjaman yang didapatkan dari bank syari'ah tersebut.

Kenapa Murābaḥah/BBA dikatakan sebagai problematika dalam transaksi syari'ah? Sebagaimana dikatakan dalam artikel yang ditulis Muhamad Nadratuzzaman Hosen (2012: 176-7), MLAB sebagai akad jual beli sangat populer diterapkan di Lembaga Keuangan Syari'ah untuk menghindari adanya riba, tetapi masyarakat merasakan bahwa tambahan dari harga pokok tersebut sama dengan tingkat suku bunga di keuangan konvensional. Oleh karenanya, ada citra negatif dalam penerapan MLAB di masyarakat awam.

\section{Transaksi Syari'ah Alternatif}

Berdasarkan apa yang dikatakan Rosadi di atas, tentang perbedaan mendasar antara sistem ekonomi Islam dan sistem ekonomi lainnya, haruslah dipahami secara menyeluruh. Demikian juga pada praktiknya, ketika sistem ekonomi Islam dijabarkan di antaranya dalam bentuk perbankan syari'ah, maka perbedaan di atas harus dipahami bahwa perbankan syari'ah memang berbeda dengan perbankan lainnya, baik ketika berkedudukan sebagai lembaga simpanan ataupun sebagai media transaksi jual beli. 
Menarik untuk dipertimbangkan tentang apa yang dikatakan al-Nabhani tentang riba, bank, dan baitul mal. Menurutnya (2009:201-203), masyarakat dalam konteks sekarang adalah masyarakat yang hidup berdasarkan sistem kapitalis. Oleh karena itu, di dalamnya tampak bank sebagai sesuatu yang urgen dalam kehidupan, demikian juga riba sebagai sesuatu yang urgen dalam kehidupan. Sistem ekonomi ini harus dirombak secara menyeluruh dan mendasar, dengan sistem ekonomi Islam. Adakalanya orang yang butuh pinjaman itu memerlukannya untuk menyambung hidupnya, atau untuk mengelola usahanya. Untuk yang pertama, Islam telah memenuhinya dengan jaminan hidup bagi tiap anggota masyarakat, dan untuk yang kedua, Islam telah memenuhinya dengan meminjami orang yang membutuhkan tanpa menggunakan riba. Apabila riba tersebut tidak ada, maka kebutuhan akan bank yang ada sekarang tentu tidak ada, dan baitul mal sajalah yang akan bertindak untuk meminjami harta tersebut. Baitul mal akan meminjami mereka yang membutuhkan untuk memenuhi dan mengelola usahanya, tetapi baitul mal tidak akan begitu saja memenuhi keinginan pengusaha kaya untuk menambah penghasilan mereka. Yang perlu diuji dari apa yang dikatakan al-Nabhani di atas adalah, apakah bank syari'ah lebih berperan sebagai bank konvensional sebagai media bagi pengusaha kaya untuk menambah penghasilan mereka, atau lebih berperan sebagai baitul mal untuk membantu mereka yang membutuhkan untuk memenuhi dan mengelola usahanya.

Mengapa bank-bank Islam menggunakan sebuah metode keuangan yang sama dengan bunga? Menurut Timur Kuran (1995:162), karena mereka kurang ahli dalam membedakan antara kesempatan investasi yang baik dan buruk. Karena kurang ahli, mereka takut jika mereka meminjamkan atas dasar pembagian laba dan rugi, mereka akan membuat banyak pilihan buruk, yang mungkin berakhir dengan lebih banyak kerugian daripada keuntungannya.

Dua hal yang terlihat berbeda padahal bersepadu adalah jenis transaksi dan nilai pengembalian. Pergeseran jenis transaksi dari transaksi pinjam meminjam uang untuk membeli barang atau sebagai modal usaha melalui transaki konvensional, menjadi transaksi jual beli barang melalui transaksi syari'ah, idealnya diikuti dengan nilai pengembalian yang sesuai, bahwa nilai pengembalian dari transaksi pinjam meminjam uang tidak boleh lebih baik dari nilai pengembalian dari transaksi jual beli barang. Terkadang seseorang memiliki transaksi konvensional karena didasari oleh nilai pengembalian yang lebih rendah daripada transaksi syari'ah. 
ljtihad, Jurnal Wacana Hukum Islam dan Kemanusiaan, Volume 13, No. 2, Desember 2013: 269-289

\section{Penutup}

Dari apa yang ditanyakan di atas, tentang apa plus-minus transaksi konvensional, apa unsur pembeda antara transaksi konvensional dengan transaksi syari'ah, dan apakah unsur pembeda itu memiliki dampak yang berbeda dari apa yang dihasilkan oleh transaksi syari'ah, dapat disimpulkan, bahwa dalam transaksi konvensional, terdapat berbagai pilihan yang didapat di antaranya melalui cara perhitungan dan penetapan bunga. Sementara yang berbeda dari transaksi konvensional dengan transaksi syari'ah adalah pergeseran jenis transaksi dari transaksi pinjam meminjam uang untuk membeli barang dengan transaksi jual beli barang. Tetapi karena dalam transaksi syari'ah, tidak terdapat berbagai pilihan sebagaimana yang ditawarkan dalam transaksi konvensional, maka unsur pembeda yang ada dalam transaksi syari'ah tidak memiliki dampak yang cukup berbeda dari apa yang dihasilkan oleh transaksi konvensional.

\section{Daftar pustaka}

Aditya, Elma Muncar. "Universalitas Ekonomi Islam”, Fokus Ekonomi, Vol. 3, No. 1 Juni 2008: 87-98.

Ahmad, Abu Umar Faruq dan M. Kabir Hassan, "Riba and Islamic Banking", Journal of Islamic Economics, Banking and Finance, t.th.: 1-33.

An-Nabhani, Taqyuddin. Membangun Sistem Ekonomi Alternatif Persepktif Islam. Surabaya: Risalah Gusti, 2009.

Antonio, Muhammad Syafi'i. Bank Syariah: Dari Teori ke Praktik. Jakarta: Gema Insani Press, 2007.

Arsyianti, Laily Dwi dan Irfan Syauqi Beik, "Analisa Tingkat Pengembalian Pembiayaan Bank Syari'ah yang Lebih Tinggi Dibandingkan dengan Bank Konvensional”. tt: 3140

Al-Shadr, Syahid Muhammad Baqir. Keunggulan Ekonomi Islam. Jakarta: Pustaka Zahra, 2002.

Athoillah, M. Anton dan Sofyan Al-Hakim, "Reinterpreting the Ratio legis of the Prohibition of Usury”, Middle-East Journal of Scientific Research, 14 (10), 2013: 1390-1400.

Borhan, Joni Tamkin Bin, "Pemikiran Pembangunan Ekonomi Berteraskan Islam”, Jurnal Usuluddin, Bil. 27 (2008): 93-107.

Chamid, Nur, "Problematika Riba dan Bunga Bank", Empirisma, Vol. 14, No. 2, Juli 2005 : 126-144.

Chapra, Mohammad Umar, What Is Islamic Economics? Islamic Research and Training Institute IDB, 2001. 
Hosen, Muhamad Nadratuzzaman, "Tinjauan Akad Murābahahah li al-Āmr bi ashirā”, Ijtihad, Vol. 12, No. 2, Desember 2012: 165-178.

Ismal, Rifki, "Assesing Moral Hazard Problem in Murabahah Financing", Journal of Islamic Economics, Banking and Finance, Vol. 5, No. 2, t.th.: 101-112.

Iswadi, Muhammad. "Ekonomi Islam: Kajian Konsep dan Model Pendekatan", Mazabib, Vol. IV, No. 1, Juni 2007: 48-57.

Kuran, Timur, "Islamic Economics and The Islamic Subeconomy", Journal of Economic Perspectives, Vol. 9, Number 4-Fall 1995: 155-173.

Perwataatmaja, Karnaen A dan Anis Byarwati. Jejake Rekam Ekonomi Islam. Jakarta: Cicero, 2008.

Saud, Mahmud Abu. Garis-garis Besar Ekonomi Islam. Jakarta: Gema Insani Press, 1996.

Presley, John R. dan John G. Sessions, "Islamic Economics: The Emergence of a New Paradigm", The Economic Journal, 104 (May 1994): 584-596.

Pujiyono, Arif, "Posisi dan Prospek Bank Syariah dalam Dunia Usaha Perbankan", Dinamika Pembangunan, Vol. 1, No. 1, Juli 2004: 45-58. 